\section{REFERENCES}

1. Coronado VG, Beck-Sague CM, Hutton MD, Davis BJ, Nicholas P, Villarreal C, et al. Transmission of multidrug-resistant Mycobacterium tuberculosis among persons with human immunodeficiency virus infection in an urban hospital epidemiological and restriction fragment length polymorphism analysis. I Infect Dis 1993;168:1052-1055.

2. Beck-Sague C, Dooley SW, Hutton MD, Otten J, Breeden A, Crawford JT, et al. Hospital outbreak of multidrug-resistant Mycobacterium tuberculosis infections: factors in transmission to staff and HIV-infected patients. JAMA 1992;268:1280-1286.

3. Aita J, Barrera L, Reniero A, Lopez B, Biglione J, Weisburd G, et al. Hospital transmission of multidrug-resistant Mycobacterium tuberculosis in Rosario, Argentina. Medicina (B Aires) 1996;56:48-50.

4. Harries AD, Kamenya A, Namarika D, Msolomba IW, Salaniponi FM, Nyangulu DS, et al. Delays in diagnosis and treatment of smear-positive tuberculosis and the incidence of tuberculosis in hospital nurses in Blantyre, Malawi. Trans R Soc Trop Med Hyg 1997;91:15-17.

5. Ritacco V, Di Lonardo M, Reneiro A, Ambroggi M, Barrera L, Dambrosi A, et al. Nosocomial spread of human immunodeficiency virus-related multidrug-resistant tuberculosis in Buenos Aires. I Infect Dis 1997; 176:637-642.

6. Wilkinson D, Crump J, Pillay M, Sturm AW. Nosocomial transmission of tuberculosis in Africa documented by restriction fragment length polymorphism. Trans R Soc Trop Med Hyg 1997;91:318.

7. Menzies D, Fanning A, Yuan L, Fitzgerald M. Tuberculosis among health care workers. $N$ Engl J Med 1995;332:92-98.

8. Sepkowitz KA. AIDS, tuberculosis and the health care worker. Clin Infect Dis 1995;20:232-242.

9. Centers for Disease Control and Prevention. Guidelines for preventing the transmission of Mycobacterium tuberculosis in health-care facilities, 1994. MMWR 1994;43(RR-13):1-132.

10. Maloney SA, Pearson ML, Gordon MT, Del Castillo R, Boyle JF, Jarvis WR. Efficacy of control measures in preventing nosocomial transmission of multidrug-resistant tuberculosis to patients and healthcare workers. Ann Intern Med 1995;122:90-95.

11. Ponce-de-Leon S. The needs of developing countries and the resources required. J Hosp Infect 1991;18(suppl A):S376-S381.

12. Harries $A D$, Maher D, Nunn P. Practical and affordable measures for the protection of health care workers from tuberculosis in low-income countries. Bull World Health Organ 1997;75:477-489.

13. Direccion General de Epidemiologia. Sistema nacional de informacion epidemiologica. Epidemiologia, Sistema Unico de Información 1999;15:7-8.

14. Latin American Demographic Center. Latin America Population Projections Calendar Year 1950-2000. Demographic Bulletin 1991;48:186.

15. Garcia-Garcia ML, Valdespino JL. Tuberculosis. In: Valdespino JL, Velasco O, Escobar A, eds. Enfermedades Tropicales en México. Diagnóstico, Tratamiento y Distribución Geográfica. México, D.F.: Secretaria de Salud; 1994:215-225.

16. Magis-Rodríguez C, Bravo-Garcia E, Anaya-López L, Uribe-Zúñiga P. La situación del SIDA en México a finales de 1998. SIDA-ETS 1998;4:143-155.

17. Garcia-Garcia ML, Jimenez-Corona A, Ferreyra-Reyes L, Rivera-Chavira B, Martinez-Tapia ME, et al. Triage of tuberculosis patients: a low cost intervention for prevention of tuberculosis transmission in hospitals. Int J Tuberc Lung Dis 1999;9(suppl 1):\$171.
18. Secretaría de Salud. Norma Oficial para el Control y Prevención de la Tuberculosis en la Atención Primaria a la Salud. Norma No. NOM-006SSAA2-1993. Official Gazette. 1995;496:20-29.

19. Arnadottir T, Rieder HL, Trebucq A, Waaler HT. Guidelines for conducting tuberculin skin test surveys in high prevalence countries. Tuber Lung Dis 1996;77 (suppl 1):1-19.

20. Sokal JE. Measurement of delayed skin-test responses. $N$ Engl J Med 1975;293:501-502.

21. Hosmer DW Jr, Lemeshow S. Applied Logistic Regression. New York, NY: Wiley Interscience; 1989:82-175.

22. Hennekens $\mathrm{CH}$, Buring J, Mayrent SL. Epidemiology in Medicine. Boston, MA: Little, Brown and Co; 1986:87-90.

23. Molina-Gamboa J, Fivera-Morales I, Ponce-de-Leon-Rosales S Prevalence of tuberculin reactivity among healthcare workers from a Mexican hospital. Infect Control Hosp Epidemiol 1994;15:319-320.

24. Cardenas-Ayala VM, Bernal-Perez J, Cabrera-Coello L, Stetler HC, Pineda-Salgado J, Guerrero-Reyes P. Tuberculosis surveys in Guerrero and new estimates of the magnitude of tuberculosis infection in Mexico [in Spanish]. Salud Publica Mex 1989;31:73-81.

25. Haas DW, Milton S, Kreiswirth BN, Brinsko VL, Bifani PJ, Schaffner W. Nosocomial transmission of a drug-sensitive W-variant Mycobacterium tuberculosis strain among patients with acquired immunodeficiency syndrome in Tennessee. Infect Control Hosp Epidemiol 1998;19:635-639.

26. Kantor HS, Poblete R, Pusateri SL Nosocomial transmission of tuberculosis from unsuspected disease. Am J Med 1988;84:833-838.

27. Ktsanes VK, Williams WL, Boudreaux VV. The cumulative risk of tuberculin skin test conversion for five years of hospital employment. $A m J$ Public Health 1986;76:65-67.

28. Behrman AJ, Shofer FS. Tuberculosis exposure and control in an urban emergency department. Ann Emerg Med 1998;31:370-375.

29. Ostrosky-Zeichner L, Rangel-Frausto S, Garcia-Romero E, Vászquez A, Ibarra MJ, Ponce de León-Rosales S. Tuberculosis in health personnel: importance of surveillance and control programs [in Spanish]. Salud Publica Mex 2000;42:48-52.

30. Ponce de Leon S, Rangel-Frausto MS, Elias-Lopez JI, Romero-Olivera C, Huertas-Jimenez M. Nosocomial infections: secular trends of a control program in Mexico [in Spanish]. Salud Publica Mex 1999;41(suppl 1):S5-S11.

31. Bailey TC, Fraser VJ, Spitznagel EL, Dunagan WC. Risk factors for a positive tuberculin skin test among employees of an urban, midwestern teaching hospital. Ann Intern Med 1995;122:580-585.

32. Menzies R, Vissandjee B, Rocher I, St Germain Y. The booster effect in two-step tuberculin testing among young adults in Montreal. Ann Intern Med 1994;120:190-198.

33. Miret-Cuadras P, Pina-Gutierrez JM, Juncosa S. Tuberculin reactivity in Bacillus Calmette-Guerin vaccinated subjects. Tuber Lung Dis 1996;77:52-58.

34. Garcia-Garcia ML, Valdespino-Gomez JL, Garcia Sancho C, Mayar-Maya ME, Palacios-Martinez M, Balandrano-Campos S, et al. Underestimation of Mycobacterium tuberculosis infection in HIV-infected subjects using reactivity to tuberculin and anergy panel. Int J Epidemiol 2000;29:369-375.

35. Granich R, Binkin N, Jarvis W, Simone P, Rieder H, Espinal M, et al. Guidelines for the prevention of tuberculosis in health-care facilities in resource-limited settings. (WHO/CDS/TB/99.269). Geneva, Switzerland: World Health Organization; 1999.

\title{
Hospital Outbreak of $P$ aeruginosa From Whirlpool Drain
}

\section{Gina Pugliese, RN, MS Martin S. Favero, PhD}

Berrouane and coworkers from the Department of Internal Medicine, University of Iowa College of Medicine, Iowa City, lowa, have reported on an outbreak of infections associated with use of a whirlpool. During a 14-month period, seven patients with hematological malignancies acquired serious infections caused by a single strain of multiresistant Pseudomonas aeruginosa. A case-control study, culture surveys, and pulsed-field gel electrophoresis implicated a whirlpool bathtub on the unit as the reservoir. All case-patients and $32 \%$ of control-patients used this bathtub $(P=.003)$. The epidemic strain was found only in cultures of samples taken from the bathtub. The drain of the whirlpool bathtub, which was contaminated with the epidemic strain, closed approximately $2.54 \mathrm{~cm}$ below the drain's strainer. Water from the faucet, which was not contaminated, became contaminated with $P$ aeruginosa from the drain when the tub was filled. The design of the drain allowed the epidemic strain to be transmitted to immunocompromised patients who used the whirlpool bathtub. Such tubs are used in many hospitals, and they may be an unrecognized source of nosocomial infections. Using whirlpool bathtubs with drains that seal at the top could eliminate this potential source of infection.

FROM: Berrouane YF, McNutt LA, Buschelman BJ, Rhomberg PR, Sanford MD, Hollis RJ, et al. Outbreak of severe Pseudomonas aeruginosa infections caused by a contaminated drain in a whirlpool bathtub. Clin Infect Dis 2000;31:1331-1337. 